\title{
Thermanaerovibrio velox sp. nov., a new anaerobic, thermophilic, organotrophic bacterium that reduces elemental sulfur, and emended description of the genus Thermanaerovibrio
}

\author{
D. G. Zavarzina, ${ }^{1}$ T. N. Zhilina, ${ }^{1}$ T. P. Tourova, ${ }^{1}$ B. B. Kuznetsov, ${ }^{2}$ \\ N. A. Kostrikina ${ }^{1}$ and E. A. Bonch-Osmolovskaya ${ }^{1}$
}

Author for correspondence: D. G. Zavarzina. Tel: +7 095135 4458. Fax: + 70951356530. e-mail: zavarzinatwo@mail.ru

Institute of Microbiology and Center

'Bioengineering'2, Russian Academy of Sciences, Prospect 60-letiya Oktyabrya 7/2, 117811, Moscow, Russia

\begin{abstract}
A moderately thermophilic, organotrophic bacterium with vibrioid cells was isolated from a sample of a cyanobacterial mat from caldera Uzon, Kamchatka, Russia, and designated strain Z-9701' . Cells of strain Z-9701' were curved, Gram-negative rods, 0.5-0.7 $\times 2.5-5.0 \mu \mathrm{m}$ in size, with tapering ends and with fast, wavy movement by means of lateral flagella located on the concave side of the cell. Colonies were small, white, irregular or round, $0.2 \mathrm{~mm}$ in diameter, and with even edges. Strain $Z-9701^{\top}$ was an obligate anaerobe with a temperature optimum at $60-65^{\circ} \mathrm{C}$ and a pH optimum at 7.3. It fermented glucose, fructose, mannose, $\mathrm{N}$-acetyl-D-glucosamine, adonite, arginine, serine, peptone, yeast extract and Casamino acids. The fermentation products formed during growth on glucose were acetate, lactate, $\mathrm{H}_{2}, \mathrm{CO}_{2}$ and ethanol. Strain Z$9701^{\top}$ reduced elemental sulfur to $\mathrm{H}_{2} \mathrm{~S}$ during organotrophic growth with glucose or peptides as energy and carbon sources. In the presence of $\mathrm{S}^{0}$, strain Z-9701' was capable of lithotrophic growth with molecular hydrogen as energy substrate and $0.1 \mathrm{~g}$ yeast extract $\mathrm{I}^{-1}$ as carbon source. Sulfate, thiosulfate, nitrate, $\mathrm{Fe}(\mathrm{III})$ and sulfite were not reduced and did not stimulate growth. The G+C content of strain Z-9701' DNA was $54.6 \mathrm{~mol} \%$. The results of 165 rDNA sequence analyses revealed that strain $\mathrm{Z}-9701^{\top}$ belongs to the cluster within the Clostridium group formed by Thermanaerovibrio acidaminovorans, Dethiosulfovibrio peptidovorans, Anaerobaculum thermoterrenum and Aminobacterium colombiense, but the level of sequence similarity with the members of this cluster was not very high (87.6-92.2\%). Among these organisms, Thermanaerovibrio acidaminovorans is phenotypically close to strain Z-9701'. However, the two organisms showed a relatively low level of similarity of their 16S rRNA sequences (92.2\%) and of DNA-DNA hybridization $(15 \pm 1 \%)$. Nevertheless, on the basis of the similar morphology and physiology of the new isolate and Thermanaerovibrio acidaminovorans, strain Z-9701 ${ }^{\top}$ was placed in the genus Thermanaerovibrio and a new species, Thermanaerovibrio velox, proposed for it. The type strain is $Z-9701^{\top}(=$ DSM 12556 ).
\end{abstract}

Keywords: vibrio, thermophile, organotroph, $\mathrm{S}^{0}$ reduction, Thermanaerovibrio velox

\section{INTRODUCTION}

Anaerobic organisms with vibrioid cells are either

The GenBank accession number for the $16 \mathrm{~S}$ rDNA sequence of strain $\mathrm{Z}-9701^{\top}$ is AF161069. sulfate (thiosulfate)-reducing bacteria or fermentative organotrophs. In total, they include nine genera, of which two comprise thermophilic bacteria. A thermophilic, vibrioid, sulfate-reducing strain was isolated from a hot spring in Yellowstone National Park and characterized as a new genus and species, Thermo- 
desulfovibrio yellowstonii (Henry et al., 1994). An organotrophic, thermophilic vibrio isolated from an anaerobic digester system was described as a new species of the genus Selenomonas, Selenomonas acidaminovorans (Guangsheng et al., 1992). This organism grew in co-culture with Methanobacterium thermoautotrophicum and was capable of fermenting diverse organic substrates, but no information was given on its ability to reduce inorganic electron acceptors. Recently, based on the comparison of 16S rRNA sequences, Selenomonas acidaminovorans was reclassified as a new genus, Thermanaerovibrio acidaminovorans (Baena et al., 1999). From a cyanobacterial mat from caldera Uzon (Kamchatka, Russia) we isolated an association of two thermophilic microorganisms, both with vibrioid cells, which grew on lactate in the presence of sulfate. The objective of this work was to isolate and identify the components of this association.

\section{METHODS}

Environmental samples. Samples of a cyanobacterial mat developing in a hot spring in caldera Uzon, Kamchatka, Russia, served as the source for enrichment and isolation of anaerobic thermophiles. The $\mathrm{pH}$ of the water in the sampling site was 6.8 and its temperature was $65^{\circ} \mathrm{C}$.

Strains. Thermodesulfovibrio yellowstonii ATCC $51303^{\mathrm{T}}$ was obtained from the ATCC, Manassas, VA, USA; Thermanaerovibrio acidaminovorans DSM 6589 ${ }^{\mathrm{T}}$ was obtained from the DSMZ, Braunschweig, Germany.

Media and cultivation. The initial enrichment was obtained using anaerobically prepared medium of the following composition $\left(\mathrm{g} \mathrm{l}^{-1}\right)$ : $\mathrm{NH}_{4} \mathrm{Cl}, 0.33 ; \mathrm{KH}_{2} \mathrm{PO}_{4}, 0.33$; $\mathrm{MgCl}_{2} \cdot 6 \mathrm{H}_{2} \mathrm{O}, 0 \cdot 33 ; \mathrm{CaCl}_{2} \cdot 6 \mathrm{H}_{2} \mathrm{O}, 0 \cdot 33 ; \mathrm{KCl}, 0 \cdot 33$; yeast extract, $0 \cdot 1 ; \mathrm{Na}_{2} \mathrm{~S} .9 \mathrm{H}_{2} \mathrm{O}, 0.5 ; \mathrm{NaHCO}_{3}, 0.7 ; \mathrm{Na}_{2} \mathrm{SO}_{4}, 2$; resazurin, 0.001. Sodium lactate $\left(50 \%\right.$ solution; $\left.10 \mathrm{ml} \mathrm{l}^{-1}\right)$; trace element solution (Kevbrin \& Zavarzin, 1992; $1 \mathrm{ml} \mathrm{l}^{-1}$ ); and vitamin solution (Wolin et al., 1963; $1 \mathrm{ml}^{-1}$ ) were also added.

The $\mathrm{pH}$ was maintained at $7 \cdot 0$ with a $\mathrm{CO}_{2}$ /sodium bicarbonate buffer. The medium was dispensed into $15 \mathrm{ml}$ Hungate tubes with screw caps and the head space $(10 \mathrm{ml})$ was filled with a $\mathrm{N}_{2} / \mathrm{CO}_{2}(8: 2, \mathrm{v} / \mathrm{v})$ gas mixture. Inoculated tubes were incubated at $55^{\circ} \mathrm{C}$. Pure cultures were obtained using the same medium by serial tenfold dilutions with subsequent isolation of single colonies in roll-tubes. For the roll-tubes, Bacto-agar $\left(2 \cdot 0 \mathrm{~g} \mathrm{l}^{-1}\right)$ was added to the medium. A pure culture of the sulfate-reducing isolate was obtained on a medium of the same composition except that sodium pyruvate $\left(3 \mathrm{~g}^{-1}\right)$ was added instead of lactate. The fermentative strain was isolated on the same medium, but glucose $\left(3 \mathrm{~g} \mathrm{l}^{-1}\right)$, yeast extract $\left(0 \cdot 25 \mathrm{~g} \mathrm{l}^{-1}\right)$ and peptone (Difco) $\left(0.25 \mathrm{~g} \mathrm{l}^{-1}\right)$ were added as substrate and sources of growth factors, and lactate and sulfate were omitted.

Physiological studies of the fermentative isolate. Utilization of various electron acceptors was tested on the same medium as used for isolation, but devoid of sulfate. Possible electron acceptors were added at the following concentrations $(\mathrm{mM})$ : sulfate, 10; thiosulfate, 10; sulfite, 1; nitrate, 10. Elemental sulfur (as sulfur flowers) was also tested at a concentration of $1 \%(\mathrm{w} / \mathrm{v})$. Tests for growth with ferric iron as an electron acceptor were done in sulfide-free medium.
$\mathrm{Fe}(\mathrm{III})$ was provided in the form of amorphous $\mathrm{Fe}(\mathrm{III})$ oxide at a concentration of $90 \mathrm{mM} \mathrm{Fe}$ (III) (Slobodkin et al., 1997). No reducing agent was added to the medium. The $\mathrm{pH}$ of the autoclaved medium containing Fe(III) was 6.8-6.9. Organic growth substrates, when tested, were added instead of glucose at a concentration of $0 \cdot 3 \%(\mathrm{w} / \mathrm{v})$. In positive cases, three subsequent transfers on the same medium were performed.

Lithotrophic growth with molecular hydrogen was tested on medium with the same mineral composition and with yeast extract $\left(0 \cdot 1 \mathrm{~g}^{-1}\right)$ as the only organic addition. Elemental sulfur served as electron acceptor. Cultivation was performed in $50 \mathrm{ml}$ bottles with screw caps, containing $10 \mathrm{ml}$ of the medium. Head space $(40 \mathrm{ml})$ was filled with $100 \%$ hydrogen.

Type strains of Thermodesulfovibrio yellowstonii and Thermanaerovibrio acidaminovorans were grown on the media described in the original publications (Henry et al., 1994; Guangsheng et al., 1992). The ability of Thermanaerovibrio acidaminovorans to reduce sulfur lithotrophically and heterotrophically was tested on the same medium with glucose and hydrogen as growth substrates and 1\% elemental sulfur.

Temperature, $\mathrm{pH}$ and $\mathrm{NaCl}$ concentration ranges for growth were determined in the basal medium with glucose, yeast extract and peptone. The $\mathrm{pH}$ range for growth was determined at $60^{\circ} \mathrm{C}$

Morphological and ultrastructural studies. The morphology of cells was studied with a Reichert Zetopan anoptral microscope. Phase-contrast micrographs of bacteria were taken using agar-coated slides (Pfennig \& Wagner, 1986). To prepare whole-cell specimens for electron microscopy, cells were sedimented by centrifugation, resuspended in tap water and negatively stained with $1 \%(\mathrm{w} / \mathrm{v})$ phosphotungstate $\mathrm{pH}$ 7. For ultrastructural studies, cells were prefixed with glutaraldehyde in culture medium for $30 \mathrm{~min}$ at ambient temperature, centrifuged, washed once with $0.15 \mathrm{M}$ pot-

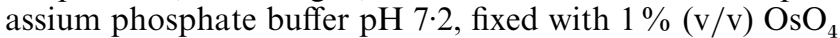
in acetate/Veronal buffer $\mathrm{pH} 7 \cdot 2$ for $18 \mathrm{~h}$ at $4{ }^{\circ} \mathrm{C}$, dehydrated and embedded in Epon 812 by standard methods. They were thin-sectioned on a LKB-4800 ultramicrotome and electron microscopy was performed with a JEM-100C microscope.

Analytical methods. Growth was followed by measuring the turbidity of medium in Hungate tubes at $600 \mathrm{~nm}$ with a Specol-10 spectrophotometer (Carl Zeiss). Glucose was quantified by the phenol- $\mathrm{H}_{2} \mathrm{SO}_{4}$ reaction (Hansson \& Phillips, 1981). Volatile fermentation products were determined on a Chrom-5 (Czechia) gas chromatograph with a flame-ionization detector using argon as carrier gas and a $0.9 \mathrm{~m} \times 3 \mathrm{~mm}$ column filled with Chromosorb 101. Hydrogen and carbon dioxide were measured by an LKhM-80 gas chromatograph (Gasochrom) equipped with a thermal conductivity detector. Hydrogen sulfide was measured by the methylene blue colorimetric method (Trüper \& Schlegel, 1964).

Determination of DNA G + C content. DNA was isolated and purified from lyzosyme- and SDS-treated cells by the method of Marmur (1961). The $\mathrm{G}+\mathrm{C}$ content was determined by the thermal denaturation method (Owen et al., 1969). Escherichia coli K-12 DNA was used as a standard. To determine DNA-DNA hybridization with the type species, Thermanaerovibrio acidaminovorans DNA was immobilized on membrane filters and reassociated under optimal 
conditions $\left(6 \times \mathrm{SSC}, 73{ }^{\circ} \mathrm{C}\right)$ for $48 \mathrm{~h}$. Reference DNA was obtained using a 'nick-translation' reaction based on $\left[{ }^{3} \mathrm{H}\right]$ cytidine (Rigby et al., 1977).

16S rDNA sequence determination and analysis. 16S rDNA was selectively amplified from genomic DNA by PCR using 5'-AGAGTTTGATCCTGGCTCAG-3' as the forward primer and 5'-TACGGTTACCTTGTTACGACTT-3' as the reverse primer (Lane, 1991). The PCR reaction was carried out in $100 \mu \mathrm{l}$ of a reaction mixture containing $1 \mu \mathrm{g}$ of DNA template, $200 \mu \mathrm{M}$ (each) primers, $200 \mu \mathrm{M}$ (each) DNPs and 3 units Tet-z polymerase (BioMaster) in reaction buffer $(100 \mathrm{mM}$ Tris $/ \mathrm{HCl} \mathrm{pH} 8 \cdot 3,500 \mathrm{mM} \mathrm{KCl}, 20 \mathrm{mM}$ $\mathrm{MgCl}_{2}$ ). Temperature cycling was done by using 30 amplification cycles of $1 \mathrm{~min}$ at $94^{\circ} \mathrm{C}, 1 \mathrm{~min}$ at $42^{\circ} \mathrm{C}$ and $1 \mathrm{~min}$ at $72{ }^{\circ} \mathrm{C}$. The final extension was carried out at $72{ }^{\circ} \mathrm{C}$ for $6 \mathrm{~min}$. The PCR products were purified using the PCR-prep kit (Promega) as recommended by the manufacturer. The 16S rDNA was sequenced in both directions by using forward and reverse universal primers. DNA sequencing was performed by using Sequenase version 2 of the VSB kit (USB).

The sequence was pre-aligned with eubacterial sequences obtained from the Ribosomal Database Project. It was then aligned with a representative set of $16 \mathrm{~S}$ rDNA sequences obtained from the Ribosomal Database Project and from recent GenBank releases by using MULTALIGN software (Corpet, 1988). Positions of sequence and alignment uncertainties were omitted and in total 1125 nucleotides were used in the analysis. Pairwise evolutionary distances were computed by using the correction of Jukes \& Cantor (1969) and transversions only (Swofford \& Olsen, 1990). The unrooted phylogenetic tree was constructed by the neighbour-joining method (Saitou \& Nei, 1987) with bootstrap analysis of 100 trees using the programs of the TREECON package (Van de Peer \& De Wachter, 1994).

Nucleotide sequence accession numbers. The GenBank accession number of the $16 \mathrm{~S}$ rDNA sequence of strain Z$9701^{\mathrm{T}}$ is AF161069. The accession numbers of the sequences used as references are as follows: Caldicellulosiruptor owensensis $\mathrm{OL}^{\mathrm{T}}$, U80596; Dictyoglomus thermophilum H-6$12^{\mathrm{T}}$, X69194; Desulfitobacterium dehalogenans JW/IU$\mathrm{DC}^{\mathrm{T}}$, U40078; Desulfotomaculum nigrificans NCIMB $8395^{\mathrm{T}}$, X62176; Moorella thermoacetica LJDT, X58352; Thermoanaerobacter ethanolicus JW-200 ${ }^{\mathrm{T}}$, L09162; Anaerobranca horikoshii JW/YL-138 ${ }^{\mathrm{T}}$, U21809; Thermoanaerobacterium thermosulfurigenes E100-69 ${ }^{\mathrm{T}}$, L09161; Dethiosulfovibrio peptidovorans G4207 ${ }^{\mathrm{T}}$, U52817; Thermoterrabacterium ferrireducens JW/AS-Y7 ${ }^{\mathrm{T}}$, U76363; Sporomusa paucivorans DSM 3637 ${ }^{\mathrm{T}}$, M59117; Thermanaerovibrio acidaminovorans DSM 6589 ${ }^{\mathrm{T}}$, AF071414; Anaerobaculum thermoterrenum RWcit ${ }^{\mathrm{T}}$, U50711; Aminobacterium colombiense ALA-1 ${ }^{\mathrm{T}}$, AF069287.

\section{RESULTS}

\section{Enrichment and isolation}

An enrichment culture of sulfate-reducing bacteria was obtained in anaerobically prepared medium containing sulfate and lactate. After $5 \mathrm{~d}$ incubation at $55^{\circ} \mathrm{C}$, two micro-organisms, one small and one large, with vibrioid cells dominated in the medium in an approximate ratio of $3: 1$; both were highly motile. After inoculation into the same medium solidified with agar, colonies of two types appeared: small, white,
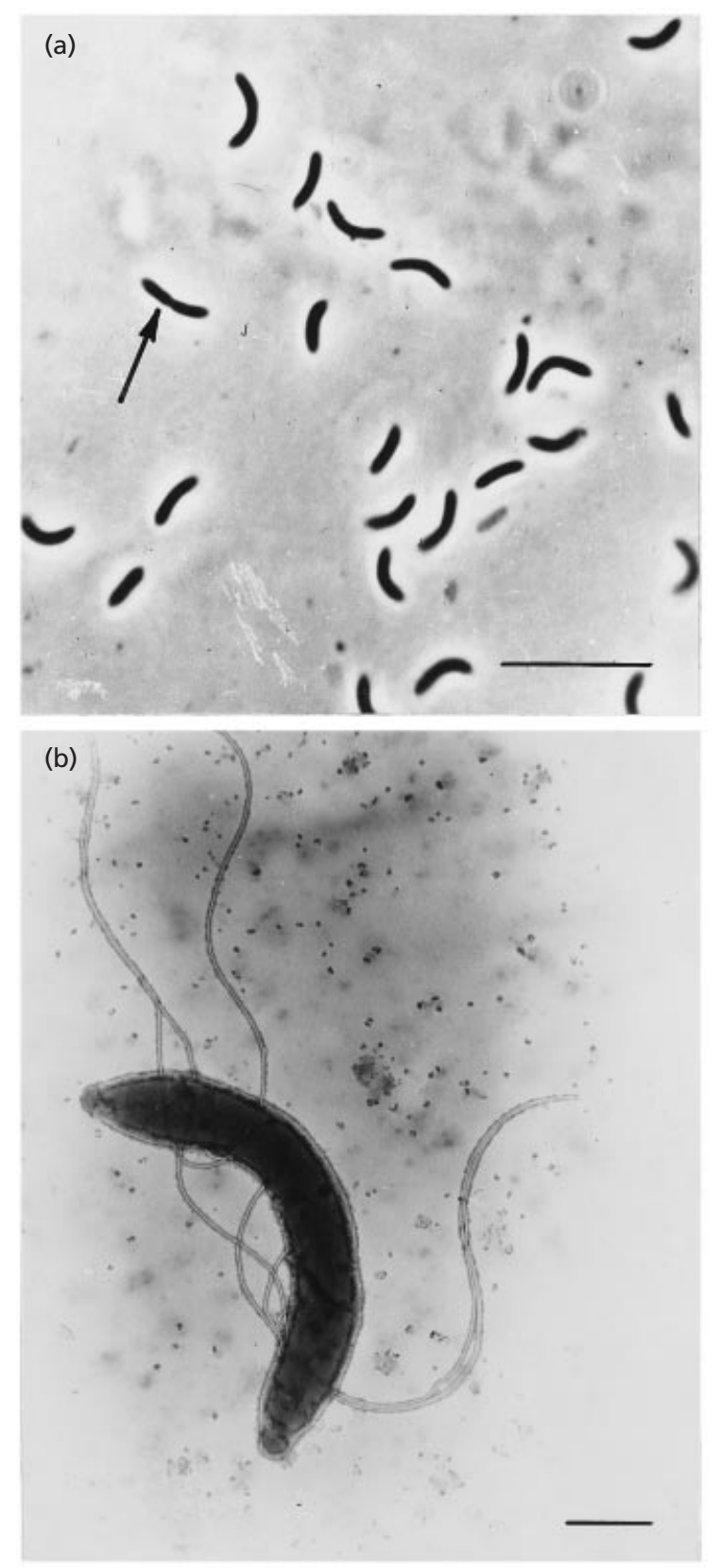

Fig. 1. Morphology of strain $Z-9701^{\top}$. (a) Cells as viewed under a phase-contrast microscope. Bar, $10 \mu \mathrm{m}$. (b) Negatively stained cell with flagella located on the concave side. Bar, $1 \mu \mathrm{m}$.

oval colonies $0 \cdot 1-0.3 \mathrm{~mm}$ in diameter with even edges and dense black centres; and small, white, irregular or round colonies $0.2 \mathrm{~mm}$ in diameter with even edges. Both organisms were isolated in pure culture.

The colonies of the first type contained small, vibrioid cells. This strain was designated Z-9702. It showed $92 \%$ DNA-DNA hybridization with the type strain of Thermodesulfovibrio yellowstonii, ATCC $51303^{\mathrm{T}}$ (Henry et al., 1994) and was identified as a strain of this species. Unlike ATCC $51303^{\mathrm{T}}$, Z-9702 did not grow in 


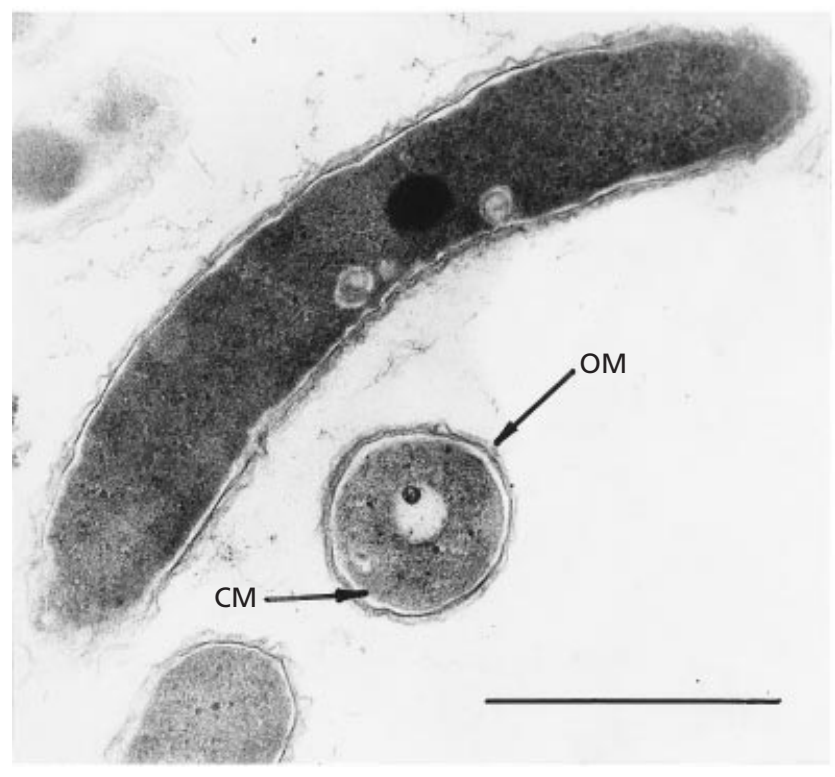

Fig. 2. Ultrastructure of strain $Z-9701^{\top}$. CM, cytoplasmic membrane; OM, outer membrane. Bar, $1 \mu \mathrm{m}$.

a medium containing lactate $\left(3 \mathrm{~g}^{-1}\right)$ and sulfate. Its growth was supported by pyruvate $\left(3 \mathrm{~g}^{-1}\right)$, formate $\left(3 \mathrm{~g} \mathrm{l}^{-1}\right)$ and molecular hydrogen.

Colonies of the second type contained large, vibrioid cells. This organism was designated strain Z-9701 ${ }^{\mathrm{T}}$. When grown in liquid medium with sulfate and lactate, isolate Z-9701 ${ }^{\mathrm{T}}$ exhibited only weak growth and no $\mathrm{H}_{2} \mathrm{~S}$ production. After transfer to medium containing glucose, growth of isolate Z-9701 ${ }^{\mathrm{T}}$ became much better. For further experiments, glucose-containing medium was used.

\section{Morphology and ultrastructural studies}

Cells of strain Z-970 ${ }^{\mathrm{T}}$ were curved rods with tapering ends, occurring singly or in pairs, and showing fast, wave-like movement (Fig. 1a). The size of the cells varied within the range $0.5-0.7 \times 2.5-5.0 \mu \mathrm{m}$ (depending on the age of the culture). Formation of spores was never observed. The organism multiplied by binary fission (see arrow in Fig. 1a). Electron microscopy of the negatively stained cells revealed lateral flagella located on the concave side of the cell (Fig. 1b). Ultrathin sections showed a typical Gramnegative cell envelope profile with a multilayered cell wall (Fig. 2).

\section{Growth characteristics}

Strain Z-9701 ${ }^{\mathrm{T}}$ was obligately anaerobic and grew only after reduction of the medium with sodium sulfide. Growth of strain Z-9701 ${ }^{\mathrm{T}}$ occurred at temperatures from 45 to $70{ }^{\circ} \mathrm{C}$, with an optimum between 60 and

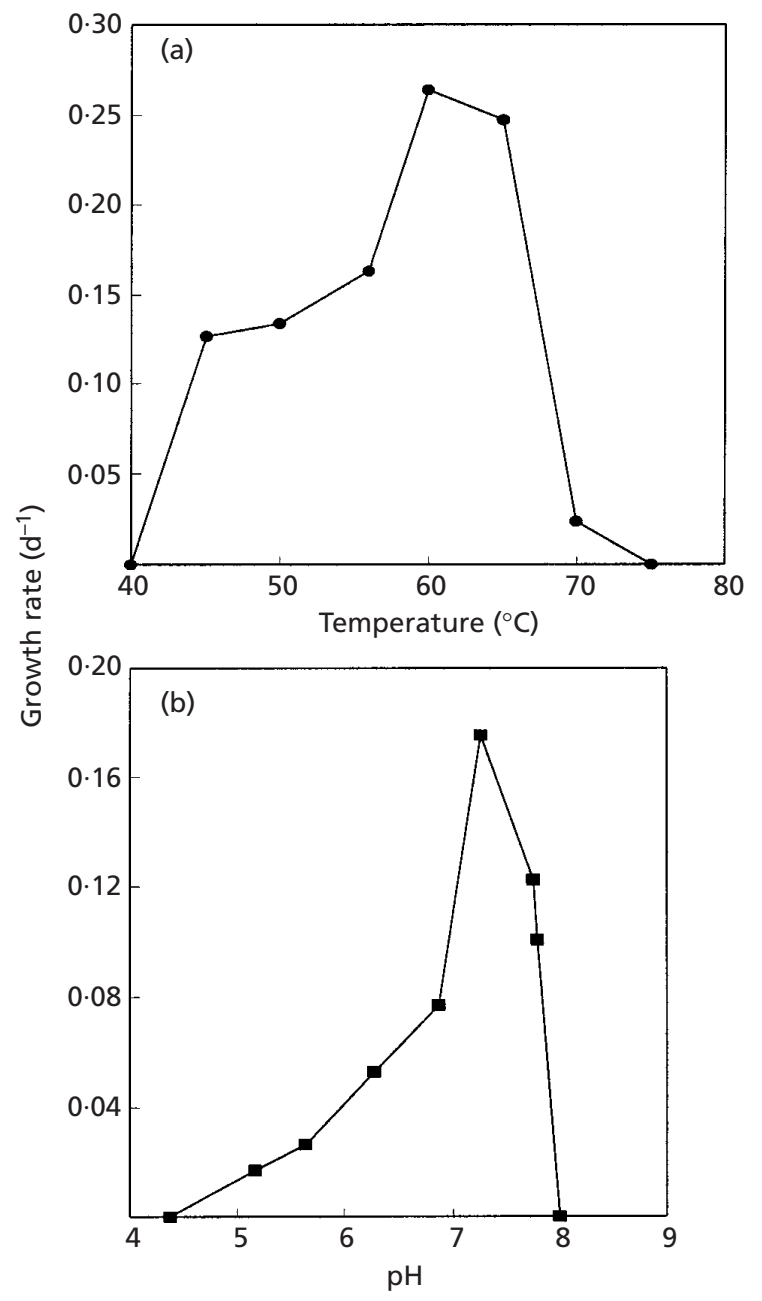

Fig. 3. (a) Effect of temperature on the growth of strain Z$9701^{\top}$. (b) Effect of $\mathrm{pH}$ on the growth of strain Z-9701 ${ }^{\top}$. The $\mathrm{pH}$ was determined at $60^{\circ} \mathrm{C}$ and initial $\mathrm{pH}$ values are plotted.

$65^{\circ} \mathrm{C}$ (Fig. 3a). The pH optimum for growth was at $7 \cdot 3$; no growth was obtained at $\mathrm{pH} 4 \cdot 5$ or $\mathrm{pH} 8 \cdot 0$ (Fig. $3 b)$. $\mathrm{NaCl}$ was not required for growth. Growth occurred at $\mathrm{NaCl}$ concentrations of up to $35 \mathrm{~g}^{-1}$.

Strain Z-9701 ${ }^{\mathrm{T}}$ was able to grow by fermentation of glucose, fructose, mannose, $N$-acetyl-D-glucosamine, adonite, arginine, serine, peptone, yeast extract and Casamino acids. No growth was observed on galactose, D-ribose, sorbose, D-xylose, D-cellobiose, D-maltose, D-lactose, melibiose, raffinose, sucrose, trehalose, acetate, ascorbate, butyrate, citrate, formate, glycolate, glutamate, lactate, malate, pyruvate, propionate, succinate, tartrate, L-dulcitol, L-inositol, ethanol, mannitol, methanol, propanol, L-sorbitol, betaine, L-histidine, glycerol, glycogen, DL-lysine, sarcosine, tryptone, choline, cellulose, chitin, starch or molecular hydrogen (in the absence of elemental sulfur).

Fermentation products formed during growth on 
Table 1. Growth of strain $\mathrm{Z}-9701^{\top}$ and Thermanaerovibrio acidaminovorans in the presence and absence of elemental sulfur

\begin{tabular}{|c|c|c|c|c|}
\hline \multirow[t]{2}{*}{ Organism } & \multirow[t]{2}{*}{ Substrate $\left(3 \mathrm{~g} \mathrm{l}^{-1}\right)$} & \multirow{2}{*}{$\begin{array}{c}\text { Growth rate } \\
\text { without } \mathbf{S}^{0}\left(\mathbf{d}^{-1}\right)\end{array}$} & \multicolumn{2}{|c|}{ Growth with $\mathbf{S}^{0}$} \\
\hline & & & Growth rate $\left(d^{-1}\right)$ & $\begin{array}{l}\mathrm{H}_{2} \mathrm{~S} \text { formed } \\
\quad\left(\mathrm{mM} \mathrm{l^{-1 } )}\right.\end{array}$ \\
\hline \multirow[t]{8}{*}{ Strain Z-9701 ${ }^{\mathrm{T}}$} & Peptone & $0 \cdot 24$ & $0 \cdot 40$ & $8 \cdot 2$ \\
\hline & Yeast extract & $0 \cdot 26$ & $0 \cdot 37$ & $7 \cdot 2$ \\
\hline & Trypticase & ND & $0 \cdot 35$ & $6 \cdot 2$ \\
\hline & Casamino acids & $0 \cdot 43$ & $0 \cdot 50$ & $5 \cdot 3$ \\
\hline & Glucose & $0 \cdot 64$ & $1 \cdot 15$ & $3 \cdot 5$ \\
\hline & $\begin{array}{l}\mathrm{H}_{2} \text { in the presence of yeast } \\
\text { extract }\left(0 \cdot 1 \mathrm{~g} \mathrm{l}^{-1}\right)\end{array}$ & No growth & $0 \cdot 20$ & $13 \cdot 1$ \\
\hline & $\mathrm{H}_{2}$ & No growth & No growth & 0 \\
\hline & Control* & No growth & No growth & 0 \\
\hline \multirow{4}{*}{$\begin{array}{l}\text { Thermanaerovibrio } \\
\text { acidaminovorans }\end{array}$} & Glucose & No growth & No growth & 0 \\
\hline & $\begin{array}{l}\mathrm{H}_{2} \text { in the presence of yeast } \\
\text { extract }\left(0 \cdot 1 \mathrm{~g} \mathrm{l}^{-1}\right)\end{array}$ & No growth & $0 \cdot 10$ & $5 \cdot 1$ \\
\hline & $\mathrm{H}_{2}$ & No growth & No growth & 0 \\
\hline & Control* & No growth & No growth & 0 \\
\hline
\end{tabular}

ND, Not determined.

* No substrate, $0 \cdot 1 \mathrm{~g}$ yeast extract $1^{-1}$.

glucose were acetate, lactate, $\mathrm{CO}_{2}, \mathrm{H}_{2}$ and ethanol. Utilization of $10 \mathrm{mM}$ glucose resulted in production of $7 \mathrm{mM} \mathrm{H}_{2}, 2.3 \mathrm{mM}$ ethanol and $5.3 \mathrm{mM}$ acetate.

Elemental sulfur was found to stimulate the growth rate of strain $\mathrm{Z}-9701^{\mathrm{T}}$ approximately twofold on glucose, peptone, yeast extract, trypticase and Casamino acids (Table 1). Concurrently with growth, elemental sulfur was reduced to hydrogen sulfide. In the presence of elemental sulfur, strain Z-9701 ${ }^{\mathrm{T}}$ was capable of lithotrophic growth with molecular hydrogen; $0 \cdot 1 \mathrm{~g}$ yeast extract $1^{-1}$ was required. Lithotrophic growth of isolate Z-9701 ${ }^{\mathrm{T}}$ was stable and did not decrease after three consequent transfers on the same medium. Sulfate, thiosulfate, nitrate, Fe(III) and sulfite were not reduced and did not stimulate growth. The presence of peptone $\left(0.25 \mathrm{~g} \mathrm{l}^{-1}\right)$ and yeast extract $\left(0.25 \mathrm{~g} \mathrm{1}^{-1}\right)$ stimulated growth rate and cell yield, the latter being 50 times higher than on glucose.

Thermanaerovibrio acidaminovorans DSM 6589 ${ }^{\mathrm{T}}$ was tested for the ability to reduce elemental sulfur. Sulfur ( $1 \%$ ) inhibited the growth of Thermanaerovibrio acidaminovorans on the medium with glucose, but it was found that the organism could grow lithotrophically with $\mathrm{H}_{2}$ and $\mathrm{S}^{0}$ (Table 1).

\section{DNA analysis}

The $\mathrm{G}+\mathrm{C}$ content of strain Z-9701 ${ }^{\mathrm{T}}$ DNA was $54.6 \mathrm{~mol} \%$. DNA-DNA hybridization with Thermanaerovibrio acidaminovorans DSM 6589 ${ }^{\mathrm{T}}$ was $15 \pm 1 \%$.

\section{Phylogenetic analysis}

The almost complete sequence of the 16S rDNA (1476 nucleotides) of strain $\mathrm{Z}-9701^{\mathrm{T}}$ covering the region between positions 8 and 1494 (E. coli numbering) was determined. A preliminary phylogenetic analysis performed with representatives of the domain Bacteria revealed that the new isolate $\mathrm{Z}-9701^{\mathrm{T}}$ was a member of the Bacillus-Clostridium subphylum of the Grampositive bacteria. Several phylogenetic trees were constructed by changing the spectrum of reference organisms. These trees demonstrated that strain Z$9701^{\mathrm{T}}$ was a member of Clostridium group which includes at least 19 defined clusters and several lines of descent (Collins et al., 1994). A final comparison of 1125 nucleotides of the 16S rDNA sequences of strain Z-9701 ${ }^{\mathrm{T}}$ and 16 reference strains of the Clostridium group was carried out and used for reconstruction of a phylogenetic tree (Fig. 4) and calculation of sequence similarity. The tree showed strain Z- $9701^{\mathrm{T}}$ to form a monophyletic cluster $(92.2 \%$ sequence similarity, bootstrap value $99 \%$ ) with Thermanaerovibrio (Selenomonas) acidaminovorans (Guangsheng et al., 1992; Baena et al., 1999). More distant relatedness was found with Aminobacterium colombiense (Baena et al., 1998) (89.6\% sequence similarity), Dethiosulfovibrio peptidovorans (Magot et al., 1997) (88.0\% sequence similarity) and Anaerobaculum thermoterrenum (Rees et al., 1997) (87.6\% sequence similarity). These organisms formed with strain Z-9701 ${ }^{\mathrm{T}}$ a new cluster of the Clostridium group with the highest level of bootstrap probability $(100 \%)$. This cluster was peripherally 


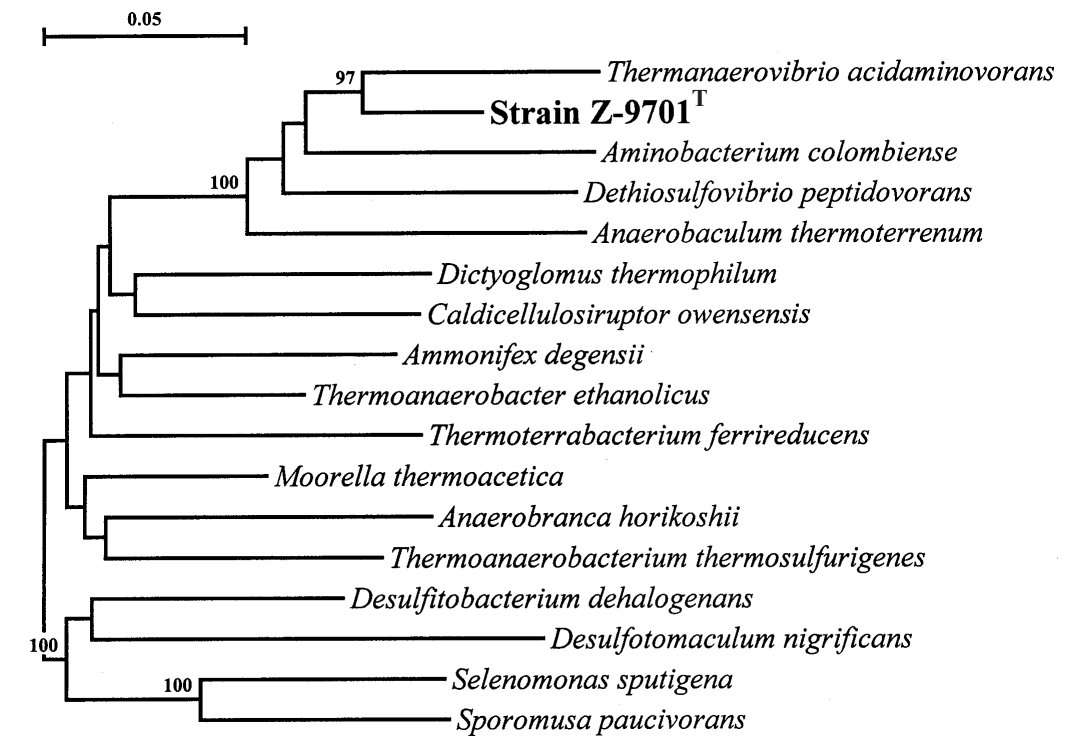

Fig. 4. Unrooted phylogenetic tree showing the position of strain $Z-9701^{\top}$ among members of the Clostridium group of the Bacillus-Clostridium phylum of the Gram-positive bacteria. Bootstrap values (expressed as a percentage of 100 replications) are shown at branch points; values greater than 95 were considered significant. Scale-bar represents the JukesCantor distance. related to cluster V of the Clostridium group (Collins et al., 1994), consisting of the genus Thermoanaerobacter, with a level of sequence similarity in the range $88 \cdot 0-88 \cdot 8 \%$. The level of $16 \mathrm{~S}$ rDNA sequence similarity between strain Z-9701 ${ }^{\mathrm{T}}$ and other members of the Clostridium group analysed was $83 \cdot 1-86 \cdot 6 \%$. A direct comparison of 1468 nucleotides of the $16 \mathrm{~S}$ rDNA sequence of strain Z-9701 ${ }^{\mathrm{T}}$ with those of its closest relative, Thermanaerovibrio acidaminovorans, was carried out and the level of sequence similarity was found to be $92.2 \%$.

\section{DISCUSSION}

Production of organic matter in thermophilic cyanobacterial mats is accompanied by its efficient destruction, mostly anaerobic (Ward et al., 1984; BonchOsmolovskaya et al., 1987). Cyanobacterial mats have served as the source for isolation of many new thermophilic prokaryotes, among them organotrophic anaerobes (Lowe et al., 1993), methanogens (Zeikus et al., 1980; Nozhevnikova \& Yagodina, 1982), and sulfate- and sulfur-reducing bacteria (Zeikus et al., 1983; Bonch-Osmolovskaya, 1994). The latter group comprised thermophilic, sulfur-reducing bacteria of different metabolic types: lithotrophic sulfur-respiring bacteria of the genus Desulfurella (BonchOsmolovskaya et al., 1990; Miroshnichenko et al., 1998) and anaerobic organotrophs which reduced elemental sulfur during the course of fermentation and belonged to the genus Thermoanaerobacter (BonchOsmolovskaya et al., 1997).

A lactate-utilizing, sulfate-reducing enrichment obtained from a cyanobacterial mat was found to contain two forms of micro-organism, both with vibrioid cells. In pure culture neither of them was capable of sulfate reduction with lactate as growth substrate. It might therefore be assumed that the two organisms formed a syntrophic association, in which one organism was producing hydrogen from lactate and the other one used the hydrogen for sulfate reduction. Indeed, the organism with smaller cells, strain Z-9702, was identified as Thermodesulfovibrio yellowstonii (Henry et al., 1994), based on the high level of DNA-DNA hybridization $(92 \%)$ with the type strain, ATCC $51303^{\mathrm{T}}$. Strain Z-9702 differed from ATCC $51303^{\mathrm{T}}$ in its inability to grow on lactatecontaining medium. Its only growth substrates were molecular hydrogen, formate and pyruvate. Growth and sulfate reduction on lactate-containing medium was possible for strain Z-9702 only in co-culture with strain Z-9701 ${ }^{\mathrm{T}}$, which probably produced molecular hydrogen from lactate.

An organism with larger cells (strain Z-9701 ${ }^{\mathrm{T}}$ ) was found to be an organotroph, fermenting numerous organic substrates. It was also found that elemental sulfur stimulated its growth on fermentable substrates - a phenomenon described previously for many organotrophic, thermophilic prokaryotes (Fiala \& Stetter, 1986; Bonch-Osmolovskaya \& Miroshnichenko, 1994; Slobodkin \& Bonch-Osmolovskaya, 1994; Bonch-Osmolovskaya et al., 1997). Strain Z-9701 ${ }^{\mathrm{T}}$ differs from other organotrophic, sulfurreducing thermophiles in its ability to grow lithotrophically with molecular hydrogen and elemental sulfur. The original description of Thermanaerovibrio acidaminovorans (formally Selenomonas acidaminovorans) includes reference to an inhibitory effect of elemental sulfur on its growth on glucose (Guangsheng et al., 1992). However, we found that this organism is able to grow lithotrophically with molecular hydrogen and elemental sulfur. We consider this feature to be an important characteristic of the genus Thermanaerovibrio. Recently, the widespread ability of thermophilic prokaryotes to reduce ferric iron lithotrophically was reported (Vagras et al., 1998; Slobodkin et al., 1999). Our finding prompts the 
Table 2. Comparison of phenotypic characteristics of anaerobic bacteria with Gram-negative, curved, rod-shaped cells

\begin{tabular}{|c|c|c|c|c|c|}
\hline \multirow[t]{2}{*}{ Character } & \multicolumn{2}{|c|}{ Family Bacteroidaceae } & \multirow{2}{*}{$\begin{array}{c}\text { Thermodesulfovibrio } \\
\text { yellowstonii } \dagger\end{array}$} & \multirow{2}{*}{$\begin{array}{c}\text { Thermanaerovibrio } \\
\text { acidaminovorans }\end{array}$} & \multirow[t]{2}{*}{ Strain Z-9701 ${ }^{\mathrm{T}}$} \\
\hline & $\begin{array}{c}\text { Genus } \\
\text { Selenomonas }\end{array}$ & $\begin{array}{c}\text { Genus } \\
\text { Succinivibrio }\end{array}$ & & & \\
\hline Cell shape & $\begin{array}{l}\text { Curved to } \\
\text { helical rods }\end{array}$ & Curved rods & Curved rods & Curved rods & Curved rods \\
\hline Cell size $(\mu \mathrm{m})$ & $0 \cdot 9-1 \cdot 1 \times 3 \cdot 0-6 \cdot 0$ & $0 \cdot 4-0 \cdot 6 \times 1 \cdot 0-7 \cdot 0$ & $0.3 \times 1.5$ & $0 \cdot 5-0 \cdot 6 \times 2 \cdot 5-3 \cdot 0$ & $0.5-0.7 \times 2.5-5.0$ \\
\hline \multicolumn{6}{|l|}{ Flagellation: } \\
\hline Polar, monotrichous & - & + & + & - & - \\
\hline $\begin{array}{l}\text { Lateral tuft on concave side } \\
\text { of cell }\end{array}$ & + & - & - & + & + \\
\hline Optimum temperature $\left({ }^{\circ} \mathrm{C}\right)$ & 37 & $30-39$ & 65 & $50-55$ & $60-65$ \\
\hline \multicolumn{6}{|l|}{ Type of metabolism: } \\
\hline Fermentative & + & + & - & + & + \\
\hline Sulfate reduction & - & - & + & - & - \\
\hline Glucose fermentation products & $\begin{array}{l}\text { Propionate, acetate, } \\
\text { lactate, succinate }\end{array}$ & $\begin{array}{l}\text { Succinate, acetate, } \\
\text { formate, lactate, } \mathrm{CO}_{2}\end{array}$ & - & Acetate, $\mathrm{H}_{2}$ & $\begin{array}{l}\text { Acetate, lactate, } \mathrm{H}_{2}, \\
\mathrm{CO}_{2} \text {, ethanol }\end{array}$ \\
\hline DNA G $+\mathrm{C}$ content $(\mathrm{mol} \%)$ & $54 \cdot 0-61 \cdot 0$ & ND & $29 \cdot 5$ & $56 \cdot 5$ & $54 \cdot 6$ \\
\hline
\end{tabular}

ND, Not determined.

* Data obtained from Holdeman et al. (1984).

$\dagger$ Data obtained from Henry et al. (1994).

\$ Data obtained from Guangsheng et al. (1992).

suggestion that the ability to grow lithotrophically with hydrogen and elemental sulfur might be shown by a much wider range of organisms than just the highly specialized, sulfur-respiring lithotrophs.

Phenotypically, strain Z-9701 ${ }^{\mathrm{T}}$ is rather close to Thermanaerovibrio (Selenomonas) acidaminovorans (Guangsheng et al., 1992; Baena et al., 1999), the only thermophilic, anaerobic organotroph with vibrioid cells described previously. The two organisms have similar morphology and physiology (Table 2), and have a close DNA G + C content, although the level of DNA-DNA hybridization was rather low $(15 \pm 1 \%)$.

Comparison of the $16 \mathrm{~S}$ rDNA sequences showed that, in spite of its Gram-negative cell wall structure, strain Z-9701 ${ }^{\mathrm{T}}$ belongs to the Bacillus - Clostridium phylum of the Gram-positive bacteria. Within this phylum, strain Z-9701 ${ }^{\mathrm{T}}$ belongs to a new line of descent of the Clostridium group which comprises some new Gramnegative genera, Thermanaerovibrio acidaminovorans, Aminobacterium colombiense, Dethiosulfovibrio peptidovorans and Anaerobaculum thermoterrenum. The degree of similarity between the 16S rRNA sequences of strain Z-9701 ${ }^{\mathrm{T}}$ and its closest relative, Thermanaerovibrio acidaminovorans, was found to be at the level of generic differentiation $(92 \cdot 2 \%)$. Nevertheless, taking into consideration the significant phenotypic similarity of Thermanaerovibrio acidaminovorans and our new isolate, we propose to placing it in the genus Thermanaerovibrio.

Strain Z-9701 ${ }^{\mathrm{T}}$ differs from Thermanaerovibrio acidaminovorans in its ability to reduce elemental sulfur during organotrophic growth and in the stimulating effect sulfur reduction has on its growth. Strain Z$9701^{\mathrm{T}}$ is unable to grow on succinate whilst Thermanaerovibrio acidaminovorans decarboxylates succinate to propionate. Thermanaerovibrio acidaminovorans degrades glucose to acetate and $\mathrm{H}_{2}$, while strain $\mathrm{Z}$ $9701^{\mathrm{T}}$ ferments it to acetate, lactate, $\mathrm{CO}_{2}, \mathrm{H}_{2}$ and ethanol. Based on its phenotypic and genotypic differences compared to Thermanaerovibrio acidaminovorans, we propose a new species for strain Z-9701 ${ }^{\mathrm{T}}$, Thermanaerovibrio velox.

\section{Emended description of genus Thermanaerovibrio (Baena et al. 1999)}

Thermanaerovibrio (Therm.an.ae.ro.vib'ri.o. Gr. adj. thermos hot; Gr. pref. an not; Gr. n. aer air; M.L. masc. n. vibrio that vibrates; M.L. masc. n. Thermanaerovibrio a thermophilic vibrating anaerobe).

Strictly anaerobic, curved cells. Motile by means of lateral flagella, located on the concave side of the cell. Gram-negative. Non-spore-forming. Multiplication occurs by binary fission. Thermophilic. Neutrophilic. Grows chemo-organotrophically with fermentable substrates or lithoheterotrophically with molecular hydrogen and elemental sulfur, reducing the sulfur to $\mathrm{H}_{2} \mathrm{~S}$. The $\mathrm{G}+\mathrm{C}$ content of the DNA is from 54.5 to $56.5 \mathrm{~mol} \%$. Habitats are granular methanogenic sludge and neutral hot springs. The type species is Thermanaerovibrio acidaminovorans $\mathrm{Su} 883^{\mathrm{T}}$ (= DSM $\left.6589^{\mathrm{T}}\right)$.

\section{Description of Thermanaerovibrio velox sp. nov.}

Thermanaerovibrio velox (ve'lox. L. adj. velox quick, fast, motile).

Cells are curved rods, $0 \cdot 5-0 \cdot 7 \times 2 \cdot 5-5 \cdot 0 \mu \mathrm{m}$ in size, with wave-like movement by means of lateral flagella located on the concave side of the cell. Colonies are small, white, irregular or round, $0.2 \mathrm{~mm}$ in diameter, and with an even edge. The cell wall has a Gramnegative structure. Non-spore-forming. Multiplication 
occurs by binary fission. Growth occurs in a temperature range from 45 to $70{ }^{\circ} \mathrm{C}$, with an optimum between 60 and $65^{\circ} \mathrm{C}$, and in a $\mathrm{pH}$ range from 4.5 to $8 \cdot 0$, with an optimum at $\mathrm{pH} 7 \cdot 3$. Ferments glucose, fructose, mannose, $N$-acetyl-D-glucosamine, adonite, arginine, serine, peptone, yeast extract and Casamino acids. When grown on glucose, produces acetate, lactate, $\mathrm{H}_{2}, \mathrm{CO}_{2}$ and ethanol. No growth occurs on galactose, ribose, sorbose, xylose, cellobiose, maltose, lactose, melibiose, raffinose, sucrose, trehalose, acetate, ascorbate, butyrate, citrate, formate, glycolate, glutamate, lactate, malate, pyruvate, propionate, succinate, tartrate, L-dulcitol, L-inositol, ethanol, mannitol, methanol, propanol, L-sorbitol, betaine, Lhistidine, glycerol, glycogen, DL-lysine, sarcosine, tryptone, choline, cellulose, chitin, starch or molecular hydrogen (in the absence of elemental sulfur). Yeast extract $\left(0.25 \mathrm{~g}^{-1}\right)$ and peptone $\left(0.25 \mathrm{~g} \mathrm{l}^{-1}\right)$ stimulate organotrophic growth on glucose. Yeast extract $\left(0 \cdot 1 \mathrm{~g} \mathrm{l}^{-1}\right)$ is required for lithotrophic growth with $\mathrm{H}_{2}$ and $\mathrm{S}^{0}$. Elemental sulfur is reduced to $\mathrm{H}_{2} \mathrm{~S}$ during, and stimulates, organotrophic growth with glucose, peptone, yeast extract, trypticase and Casamino acids, or lithotrophic growth with molecular hydrogen. Sulfate, thiosulfate, nitrate, $\mathrm{Fe}(\mathrm{III})$ and sulfite are not reduced and do not stimulate growth. The DNA G $+\mathrm{C}$ content is $54.6 \mathrm{~mol} \%$. The organism was isolated from a thermophilic cyanobacterial mat from caldera Uzon, Kamchatka, Russia. The type strain is Z-9701 ${ }^{\mathrm{T}}$ (= DSM $12556^{\mathrm{T}}$ ).

\section{ACKNOWLEDGEMENTS}

We are grateful to A. M. Lysenko for determination of the DNA G + C content and DNA-DNA hybridization, and to A. V. Lebedinsky for helpful discussion. This work was supported by the Ministry of Science of Russian Federation, 'Biodiversity' program, 'Biodiversity of extremophilic micro-organisms and their communities' project, and by the Russian Foundation of Basic Research, grants 99-04-48360 and 99-05-65267.

\section{REFERENCES}

Baena, S., Fardeau, M. L., Labat, M., Ollivier, B., Thomas, P., Garcia, J. L. \& Patel, B. K. C. (1998). Aminobacterium colombiense gen. nov., sp. nov., an amino acid-degrading anaerobe isolated from anaerobic sludge. Anaerobe 4, 241-250.

Baena, S., Fardeau, M.-L., Woo, T. H. S., Ollivier, O., Labat, M. \& Patel, B. K. C. (1999). Phylogenetic relationships of three aminoacid-utilizing anaerobes, Selenomonas acidaminovorans, 'Selenomonas acidaminophila' and Eubacterium acidaminophilum, as inferred from partial 16S rDNA nucleotide sequences and proposal of Thermanaerovibrio acidaminovorans gen. nov., comb. nov. and Anaeromusa acidaminophila gen. nov., comb. nov. Int J Syst Bacteriol 49, 969-974.

Bonch-Osmolovskaya, E. A. (1994). Bacterial sulfur reduction in hot vents. FEMS Microbiol Rev 15, 65-67.

Bonch-Osmolovskaya, E. A. \& Miroshnichenko, M. L. (1994). The influence of molecular hydrogen and elemental sulfur on the metabolism of extremely thermophilic Archea of genus Thermococcus. Microbiology (English translation of Mikrobiologiya) 63, 777-782.
Bonch-Osmolovskaya, E. A., Gorlenko, V. M., Karpov, G. A. \& Starynin, D. A. (1987). Anaerobic destruction of the organic matter in microbial mats of the Thermophilny Spring in the Uzon caldera in Kamchatka. Microbiology (English translation of Mikrobiologiya) 56, 1022-1028.

Bonch-Osmolovskaya, E. A., Sokolova, T. G., Kostrikina, N. A. \& Zavarzin, G. A. (1990). Desulfurella acetivorans gen. nov., sp. nov. - a new thermophilic sulfur-reducing eubacterium. Arch Microbiol 153, 151-155.

Bonch-Osmolovskaya, E. A., Miroshnichenko, M. L., Chernykh, H. A., Kostrikina, N. A., Pikuta, E. V. \& Rainey, F. A. (1997). Reduction of elemental sulfur by moderately thermophilic organotrophic bacteria and the description of Thermoanaerobacter sulfurophilus sp. nov. Microbiology (English translation of Mikrobiologiya) 66, 581-587.

Collins, M. D., Lawson, P. A., Willems, A., Cordoba, J. J., Fernandesgarayzabal, J., Garcia, P., Cai, J., Hippe, H. \& Farrow, J. A. E. (1994). The phylogeny of the genus Clostridium: proposal of five new genera and eleven new species combinations. Int $J$ Syst Bacteriol 44, 812-826.

Corpet, F. (1988). Multiple sequence alignment with hierarchical clustering. Nucleic Acids Res 16, 10881-10890.

Fiala, G. \& Stetter, K. O. (1986). Pyrococcus furiosus sp. nov. represents a new genus of marine heterotrophic archaebacteria growing optimally at $100^{\circ} \mathrm{C}$. Arch Microbiol 145, 56-61.

Guangsheng, C., Plugge, C. M., Roelofsen, W., Houwen, F. R. \& Stams, A. J. M. (1992). Selenomonas acidaminovorans sp. nov., a versatile thermophilic proton-reducing anaerobe able to grow by decarboxylation of succinate to propionate. Arch Microbiol 157, 169-175.

Hansson, R. \& Phillips, J. (1981). Chemical composition of bacterial cells. In Manual of Methods for General Bacteriology, pp. 328-364. Edited by P. Gerhardt, R. G. E. Murray, R. N. Costilow, E. W. Nester, W. A. Wood, N. R. Krei \& G. B. Phillips. Washington, DC: American Society for Microbiology.

Henry, E. A., Devereux, D., Maki, J. S., Gilmour, C. C., Woese, C. R., Mandelco, L., Schauder, A., Remsen, C. C. \& Mitchell, R. (1994). Characterization of a new thermophilic sulfate-reducing bacterium Thermodesulfovibrio yellowstonii gen. nov. and sp. nov.: its phylogenetic relationship to Thermodesulfobacterium commune and their origins deep within the bacterial domain. Arch Microbiol 161, 62-69.

Holdeman, L. V., Kelley, R. W. \& Moore, W. E. G. (1984). Anaerobic Gram-negative straight, curved and helical rods. Family I. Bacteroidaceae. In Bergey's Manual of Systematic Bacteriology, vol. 1, pp. 602-662. Edited by N. R. Krieg \& J. G. Holt. Baltimore: Williams \& Wilkins.

Jukes, T. H. \& Cantor, C. R. (1969). Evolution of protein molecules. In Mammalian Protein Metabolism, vol. 3, pp. 21-132. Edited by H. N. Munro. New York: Academic Press.

Kevbrin, V. V. \& Zavarzin, G. A. (1992). The effect of sulfur compounds on growth of halophilic homoacetic bacterium Acetohalobium arabaticum. Microbiology (English translation of Mikrobiologiya) 61, 812-817.

Lane, D. J. (1991). 16S/23S rRNA sequencing. In Nucleic Acid Techniques in Bacterial Systematics, pp. 115-147. Edited by E. Stackebrandt \& M. Goodfellow. New York: Wiley.

Lowe, L. W., Jain, M. K. \& Zeikus, J. G. (1993). Biology, ecology, and biotechnological applications of anaerobic bacteria adapted to environmental stresses in temperature, $\mathrm{pH}$, salinity, or substrates. Microbiol Rev 57, 451-509.

Magot, M., Ravot, G., Campaignolle, X., Ollivier, B., Patel, 
B. K. C., Fardeau, M. L., Thomas, P., Crolet, J. L. \& Garcia, J. L. (1997). Dethiosulfovibrio peptidovorans gen. nov., sp. nov., a new anaerobic, slightly halophilic, thiosulfate-reducing bacterium from corroding offshore oil wells. Int $J$ Syst Bacteriol 47, 818-824.

Marmur, J. (1961). A procedure for the isolation of deoxyribonucleic acid from microorganisms. J Mol Biol 3, 208-218.

Miroshnichenko, M. L., Rainey, F. A., Hippe, H., Chernyh, N. A., Kostrikina, N. A. \& Bonch-Osmolovskaya, E. A. (1998). Desulfurella kamchatkiensis sp. nov. and Desulfurella propionica sp. nov. - sulfur-respiring thermophilic bacteria from Kamchatka thermal environments. Int $J$ Syst Bacteriol 48, 475-479.

Nozhevnikova, A. N. \& Yagodina, T. G. (1982). A thermophilic acetate-utilizing, methane-producing bacterium. Microbiology (English translation of Mikrobiologiya) 51, 642-649.

Owen, R. J., Hill, L. R. \& Lapage, S. P. (1969). Determination of DNA base compositions from melting profiles in dilute buffers. Biopolymers 7, 503-516.

Pfennig, N. \& Wagner, S. (1986). An improved method of preparing wet mounts for photomicrographs of microorganisms. J Microbiol Methods 4, 303-306.

Rees, N. G., Patel, B. K. C., Grassia, G. S. \& Sheehy, A. J. (1997). Anaerobaculum thermoterrenum gen. nov., sp. nov., a novel thermophilic bacterium which ferments citrate. Int $J$ Syst Bacteriol 47, 150-154.

Rigby, P. W., Dieckman, M., Rhodes, C. \& Berg, P. (1977). Labeling deoxyribonucleic acid to high specific activity in vitro by nicktranslation with DNA polymerase I. J Mol Biol 113, 237-245.

Saitou, N. \& Nei, M. (1987). The neighbor-joining method: a new method for constructing phylogenetic trees. Mol Biol Evol 4, 406-425.

Slobodkin, A. I. \& Bonch-Osmolovskaya, E. A. (1994). Growth and metabolic product formation by extremely thermophilic Archea of the genus Desulfurococcus in the presence and absence of elemental sulfur. Microbiology (English translation of Mikrobiologiya) 63, 981-986.
Slobodkin, A., Reysenbach, A. L., Strutz, N., Dreier, M. \& Wiegel, J. (1997). Thermoterrabacterium ferrireducens gen. nov., sp. nov., a thermophilic anaerobic dissimilatory Fe(III)-reducing bacterium from a continental hot spring. Int J Syst Bacteriol 47, 541-547.

Slobodkin, A., Jeanthon, C., L'Haridon, S., Nazina, T., Miroshnichenko, M. \& Bonch-Osmolovskaya, E. (1999). Dissimilatory reduction of $\mathrm{Fe}$ (III) by thermophilic Bacteria and Archea in deep subsurface petroleum reservoirs of Western Siberia. Curr Microbiol 39, 99-102.

Swofford, D. L. \& Olsen, G. J. (1990). Phylogeny reconstruction. In Molecular Systematics, pp. 411-501. Edited by D. M. Hillis \& C. Moritz. Sunderland: Sinauer Associates.

Trüper, H. G. \& Schlegel, H. G. (1964). Sulfur metabolism in Thiorhodaceae. Quantitative measurements on growing cells of Chromatium okenii. Antonie Leeuwenhoek 30, 225-238.

Vagras, M., Kasheff, K., Blunt-Harris, E. \& Lovley, D. (1998). Microbiological evidence for Fe(III) reduction on early Earth. Nature 395, 65-67.

Van de Peer, Y. \& De Wachter, R. (1994). TREECON for Windows: a software package for the construction and drawing of evolutionary trees for the Microsoft Windows environment. Comput Appl Biosci 10, 569-570.

Ward, D. M., Beck, E., Revsbech, N. P., Sandbeck, K. A. \& Winfrey, M. R. (1984). Decomposition of hot spring microbial mats. In Microbial Mats: Stromatolites, pp. 191-214. Edited by Y. Cohen, R. W. Castenholz \& H. O. Halvorsen. New York: Alan R. Liss.

Wolin, E. A., Wolin, M. J. \& Wolfe, R. S. (1963). Formation of methane by bacterial extracts. J Biol Chem 238, 2882-2888.

Zeikus, J. G., Ben-Bassat, A. \& Hegger, P. W. (1980). Microbiology of methanogenesis in thermal volcanic environments. $J$ Bacteriol 143, 432-440.

Zeikus, J. G., Dawson, M. A., Thompson, T. E., Ingvorsen, K. \& Hatchikian, E. C. (1983). Microbial ecology of volcanic sulfidogenesis: isolation and characterization of Thermodesulfobacterium commune gen. nov. and sp. nov. J Gen Microbiol 129, $1159-1169$. 